\title{
A note on the effects of pre-slaughter operations of llamas (Lama glama) on the concentrations of some blood constituents related to stress and carcass quality
}

\author{
Una nota sobre el efecto de las operaciones presacrificio en llamas (Lama glama) sobre las \\ concentraciones de algunos componentes sanguíneos relacionados al estrés y la calidad de la canal \\ LW Mamani-Linares ${ }^{\mathbf{a}, \mathbf{b}}, \mathbf{C}$ Gallo $^{\mathbf{b}^{*}}$ \\ aBecario MECESUP2 AUS 0601, Programa de Doctorado en Ciencias Veterinarias, Facultad de Ciencias Veterinarias, \\ Universidad Austral de Chile, Valdivia, Chile. \\ bInstituto de Ciencia Animal, Facultad Ciencias Veterinarias, Universidad Austral de Chile, Valdivia, Chile.
}

\begin{abstract}
RESUMEN
El objetivo de este trabajo fue evaluar el efecto de las operaciones presacrificio sobre indicadores fisiológicos de estrés (constituyentes sanguíneos) y de calidad de la canal ( $\mathrm{pH}$ y contusiones) en llamas bajo condiciones comerciales. Treinta llamas criadas a pastoreo, de 18-24 meses de edad y peso vivo $54,2 \pm 6,4 \mathrm{~kg}$ fueron transportadas durante $3 \mathrm{~h}$ en un vehículo a matadero. Se tomaron muestras de sangre a las llamas en predio una hora antes de cargar, después de descargar, después del reposo en matadero $(18 \mathrm{~h})$ y durante la exsanguinación. Se encontró un aumento significativo $(\mathrm{P}<0,05)$ de cortisol después del transporte $(16,9 \mathrm{ng} / \mathrm{mL})$, como también de actividad de CK después del reposo $(528,4 \mathrm{UI} / \mathrm{L})$; la concentración de $\beta$-hidroxibutirato se mantuvo en los muestreos. Se registraron 19 contusiones en 9 de las 30 canales de llamas. Las lesiones superficiales, pequeñas y de color rojo brillante, fueron las más frecuentes. La región del lomo presentó más contusiones $(57,89 \%)$, seguida del tórax $(21,05 \%)$. Las lesiones de forma irregular fueron más frecuentes $(81,25 \%)$, seguidas de circulares $(18,75 \%)$. Se concluyó que las operaciones presacrificio de llamas bajo las condiciones comerciales del estudio produjeron cambios fisiológicos similares a los observados en otras especies, que caen dentro de límites aceptables para su bienestar; sin embargo, el estrés y los efectos adversos en las canales, como las contusiones, podrían minimizarse mediante diseño de estructuras apropiadas para el manejo, aplicación de las recomendaciones de OIE para el bienestar durante el sacrificio y capacitación del personal que maneja las llamas a lo largo de la cadena cárnica en Bolivia.
\end{abstract}

Palabras clave: operaciones presacrificio, constituyentes sanguíneos, contusiones, Lama glama.

\section{SUMMARY}

The objective of the current study was to assess the effects of pre-slaughter operations in llamas on physiological (concentrations of some blood constituents) and carcass quality (pH and bruises) indicators under commercial conditions. Thirty llamas raised on pasture, 18-24 months old and average live weight of $54.2 \pm 6.4 \mathrm{~kg}$ were transported on a single $3 \mathrm{~h}$ journey in one batch to the slaughterhouse. Blood samples were taken on farm one hour before loading, after unloading, after lairage $(18 \mathrm{~h})$ and during exsanguination to measure the concentrations of various stress-related variables. Mean values for the blood variables showed a significant rise $(\mathrm{P}<0.05)$ in the concentration of cortisol immediately after transport $(16.9 \mathrm{ng} / \mathrm{mL})$, as well as CK activity after lairage (528.4 UI/L); $\beta$-hydroxybutyrate concentration showed similar mean values for the different sampling times. A total of 19 bruises were found on 9 of the carcasses. The backs (loin) of carcasses had more bruises (57.89\%), followed by thorax (21.05\%). Irregularly shaped bruises were the most frequent $(81.25 \%)$, followed by circular bruises $(18.75 \%)$. It was concluded that pre-slaughter handling of llamas under these commercial conditions produced physiological changes similar to those in other species, which fall within acceptable limits for their welfare; however stress could be reduced and adverse effects like bruises could be minimized by designing proper facilities, by following OIE recommendations on the welfare of animals during stunning and by training of personnel handling llamas all along the Bolivian meat chain.

Key words: road transport, pre-slaughter operations, blood constituents, bruising, Lama glama.

\section{INTRODUCTION}

According to Cristofanelli et al (2005), of all the South American camelids the llama has potential merits as a source of meat in the Andean highlands, producing carcasses that are significantly larger than those from alpacas. The population of llamas in Bolivia is 2,486,169, representing over $60 \%$ of the world population (INE 2008). Although conventional

Accepted: 17.04.2014.

* cgallo@uach.cl llama production systems are based on native grazing feeding and llamas are adapted to areas where coarse forage is available, Mamani-Linares and Gallo (2013 $)$ showed that supplementation of young llamas grazing native pasture with concentrate can lead to greater live weight, greater carcass weight, greater fat deposits and improved the carcass characteristics, supporting the idea that it is a good alternative in the production of llama meat, especially during the dry season when there is poor pasture availability. Moreover, llama meat can be considered a healthy food as it is characterised by a relatively low cholesterol $(39.04 \mathrm{mg} / 100 \mathrm{~g})$ and intramuscular fat content (1.56\%), and a high ratio of 
protein to fat, with an adequate amino acid composition (Mamani-Linares and Gallo 2013 ${ }^{\mathrm{b}}$ ). While there is substantial study on the effects of handling and transportation of cattle, horse, pig, sheep, goat and various wildlife species (Grandin 1997, Tadich et al 2009, Miranda-de la Lama et al 2012), no work has been carried out to assess the effects of pre-slaughter operations in llamas.

Sale and slaughter are the most common reasons for transporting llamas in Bolivia and transport time varies depending on the distance from farm to slaughterhouse. Transportation is an inevitable husbandry practice which is often considered as one of the main causes of stress, raising interest regarding animal welfare standpoints and economic losses, as it reduces carcass weight, increases bruises and negatively affects muscle pH (Gallo et al 2000, 2003). During transport, animals are exposed to a variety of potential stressors such as handling by humans, gathering, loading and unloading, motion of the vehicle, noise, vibrations, centrifugal forces, heat or cold, poor road conditions and lack of water and feed (Hartung 2003). These stressors may lead to some changes in blood constituents such as plasma concentration of glucose, cortisol, creatine kinase $(\mathrm{CK})$, lactate dehydrogenase and packed cell volume (Knowles and Warriss 2007). Bruises can occur at any point of the meat chain, due to inappropriate handling of the animal during the pre-slaughter period. Bruises are indicative of violence and pain suffered by the animals which is related to poor welfare conditions during pre-slaughter period (Strappini et al 2009). Moreover, bruises in bovine carcasses affect the quality of the carcass and the meat. Another reason for downgrading carcasses is the presence of dark, firm and dry meat. Presence of bruises is also significantly associated with increased carcass pH values (Strappini et al 2010). The OIE (2012) has issued standards for animal welfare during terrestrial transport and during slaughter that all country members should follow; therefore it is important to produce baseline information for llamas in this regard. The objective of the current study was to assess the effects of pre-slaughter operations in llamas on physiological (concentrations of some blood constituents) and carcass quality ( $\mathrm{pH}$ and bruises) indicators under commercial conditions.

\section{MATERIAL AND METHODS}

\section{ANIMALS AND PRE-SLAUGHTER CONDITIONS}

A total of 30 entire male llamas of the Kh'ara genotype were used. The animals were 18-24 months old, fed on native grass pasture, originated from one producer in the Bolivian Altiplano and were ready for slaughter. The study was carried out between September and November 2011. The day before transport to slaughter, the llamas had been gathered from the fields and led to a pen for overnight keeping (usual procedure), where they had access to barley hay.
The animals were loaded into an open roof small truck, with wooden flooring and no bedding, with a single compartment, using the usual procedures. First, the truck was parked against a natural embankment; then llamas were driven out of the corral (figure 1a) towards the back of the truck using a "human fence" which was gradually closed forcing the animals to be loaded onto the truck (figure 1b). The transport involved using a combination of road types ranging from small country lanes (10 km stone road) to secondary roads (170 km asphalt) on a single $3 \mathrm{~h}$ journey at a stocking density of approximately $110 \mathrm{~kg} / \mathrm{m}^{2}\left(0.55 \mathrm{~m}^{2}\right.$ per animal, figure 1c), over a distance of about $180 \mathrm{~km}$ with an average speed of $60 \mathrm{~km} / \mathrm{h}$. On arrival at the slaughterhouse the llamas were unloaded by again parking the truck against a natural embankment close to the lairage pens and letting them "jump" out of the truck after opening the hind door (no unloading ramp was available, figure 1d); then they were driven to the lairage pen using again a human fence. The llamas remained in lairage for $18 \mathrm{~h}$ approximately (figure 1e), and were then taken one by one to the slaughter point and slaughtered using the puntilla (figure 1f).

\section{BLOOD SAMPLING AND ANALYSES}

Blood samples were collected directly into $10 \mathrm{~mL}$ vacuum tubes (Vacutainer, Beckton Dickinson) via jugular venipuncture at 4 sampling times: one hour before loading of the llamas, immediately after unloading, after lairage and during exsanguination (at bleeding). Llamas were restrained manually in the pen by one person who placed one hand on the anterior-medial part of the neck and the other one behind the leg, pressing the llama with his body and knee, as shown in figure 1e. Blood samples were left to coagulate for about $12 \mathrm{~h}$ at room temperature; then serum was separated and frozen for further analysis. Serum cortisol concentration was determined by radioimmunoassay (RIA), using a commercial kit (Cortisol Coat-A-Count, DPC, USA); CK activity was measured by the UV-kinetic method at $340 \mathrm{~nm}$ and $37^{\circ} \mathrm{C}$ (Art. 12015 HUMAN) using a Kobas Mira Plus spectrophotometer (HITACHI 4020, Roche $^{\circledR}$ ); $\beta \mathrm{OHB}$ values were determined using an enzymatic technique based on 3-hydroxybutyrate-dehydrogenase enzyme in a spectrophotometer (HITACHI 4020, Roche $^{\circledR}$ ).

\section{CARCASS INDICATORS}

The live weights of the animals were taken on the farm before loading. The animals were slaughtered following the usual commercial procedures in Bolivia; the hot carcasses were weighed and the external fat finishing score visually appraised ( 5 = extremely abundant, $4=$ abundant, $3=$ medium 2 = slight, $1=$ scarce). The muscle $\mathrm{pH}$ ( 1 and $24 \mathrm{~h}$ post-mortem) was measured in the Longissimus thoracis muscle at the level of the 1st lumbar vertebrae, using a portable Hanna HI99163 pH meter, and following manufacturer instructions (HANNA Instruments ${ }^{\circledR}$, USA). 

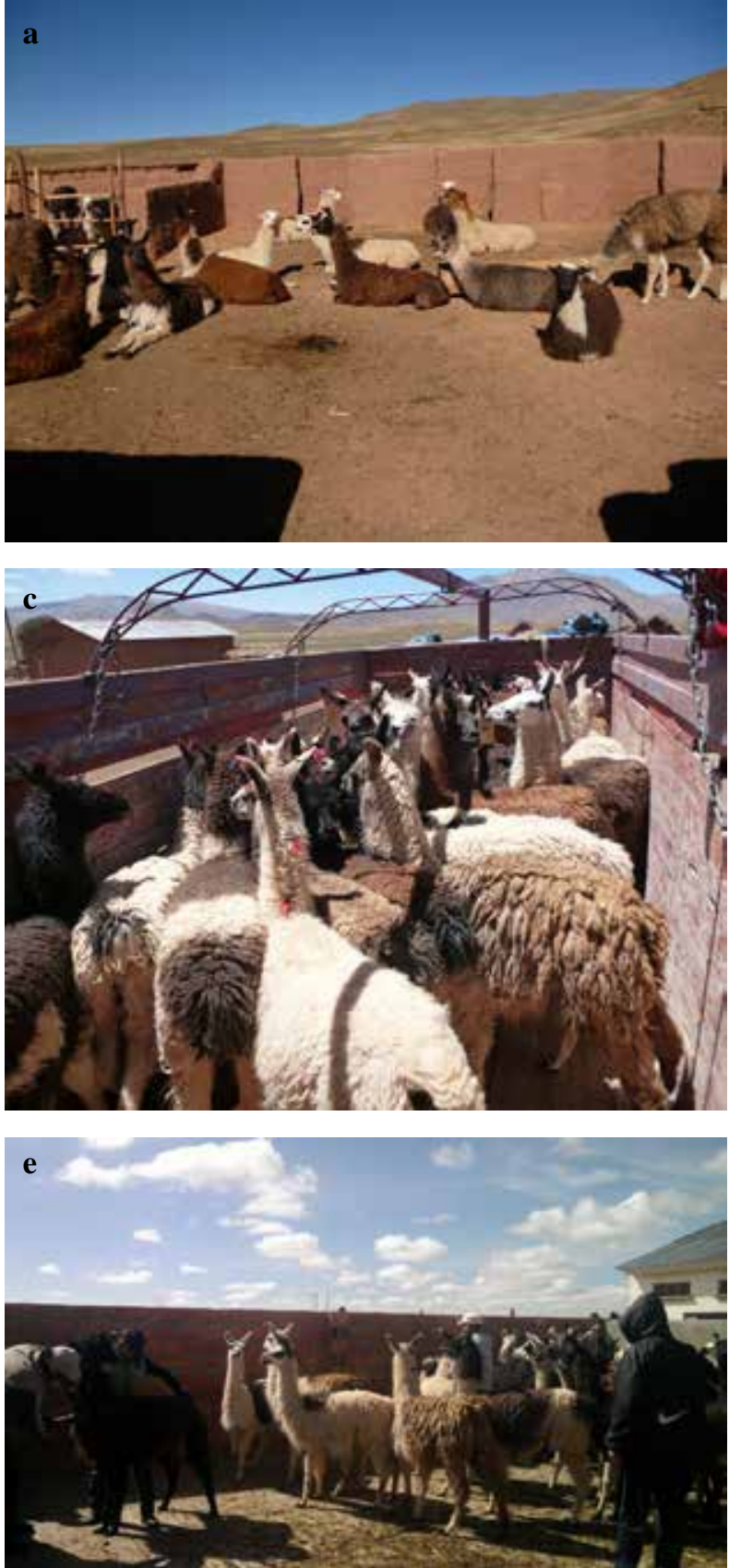
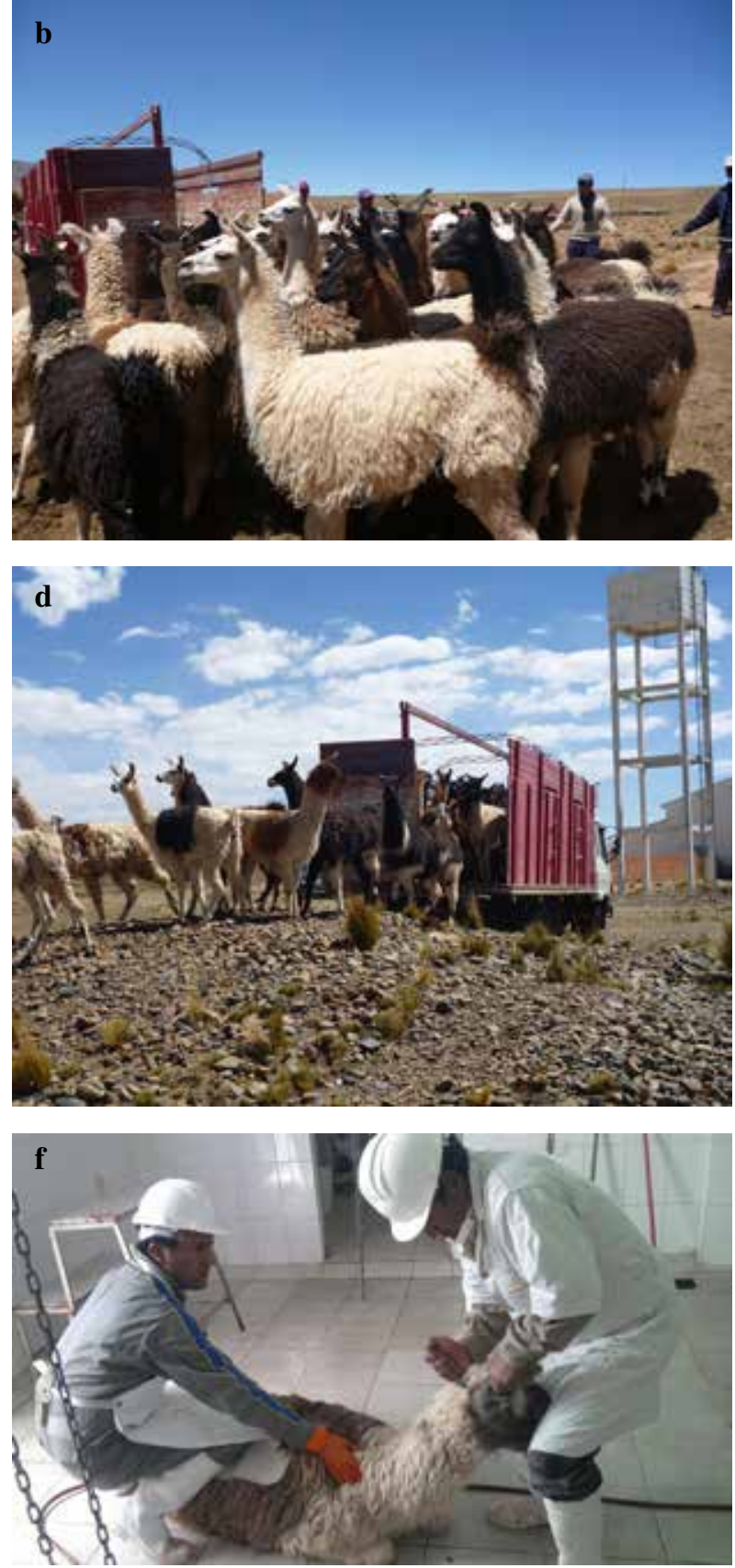

Figure 1. Pre-slaughter handling of llamas. (a) On farm, before the first blood sampling; (b) Loading; (c) Transport; (d) Unloading; (e) During lairage (showing also handling for blood sampling); (f) Slaughter/stunning using puntilla.

Manejo antemortem de las llamas: (a) en el predio, antes del primer muestreo de sangre; (b) carga; (c) transporte; (d) descarga; (e) en corrales de reposo en matadero (incluido el manejo durante el muestreo de sangre); (f) insensibilización/sacrificio usando puntilla española.

For each carcass, the presence of bruises (yes or no) was recorded. If bruises were present, the number of bruises per carcass and per anatomical site was assessed. Each bruise present on the llama carcasses was evaluated by registering its anatomical site, size, shape and colour adapting the protocol used by Strappini (2010) for cattle. The anatomical site of the bruise was recorded dividing the carcass into eight sites: leg, abdomen, thorax, shoulder, loin, neck, ischial tuberosity, coxal tuberosity (figure 2). The size of each bruise was assessed on the basis of its diameter according to the ACBSS: small: $\geq 2$ to $\leq 8 \mathrm{~cm}$; medium: 8 to $\leq 16 \mathrm{~cm}$; large: $>16 \mathrm{~cm}$. The severity of the bruises was scored by the observer according to the Chilean carcass grading classification (INN 2002) as grade 1 (only subcutaneous tissue affected); grade 2 (as grade 1, but with muscle tissue affected); grade 3 (as grades 1 and 2, plus presence of fracture). 


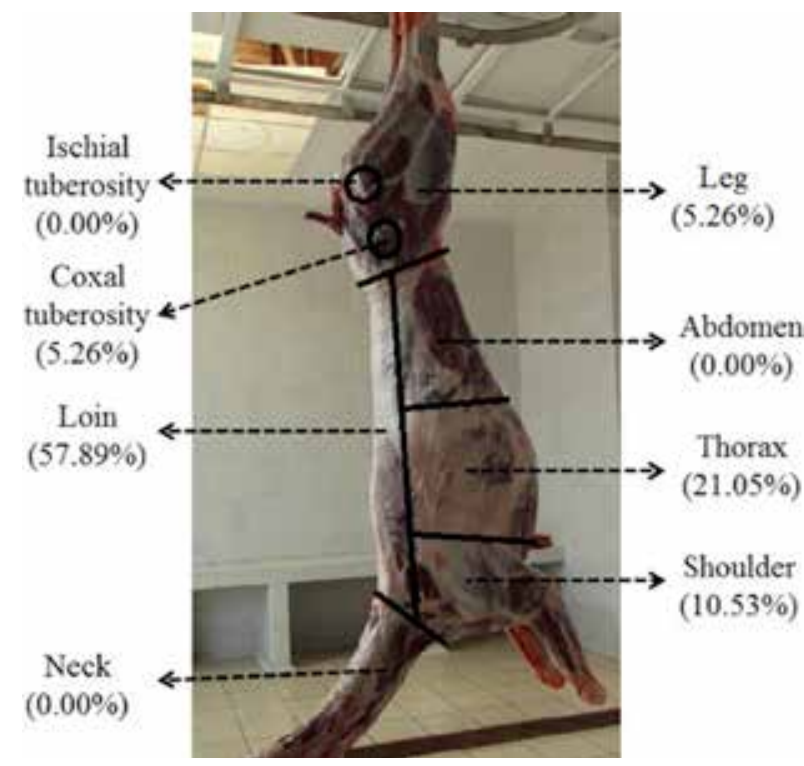

Figure 2. Distribution of bruises according to anatomical location in llama carcasses. en las canales de las llamas.

Distribución de los hematomas según su ubicación anatómica

\section{ANALYTICAL METHODS}

Descriptive statistics was used, presenting weights at slaughter and carcass $\mathrm{pH}$ data as the mean \pm standard deviations, characteristics and anatomical location of bruises in percentage. The mean values of the blood constituents at each sampling time were analysed by means of an analysis of variance (ANOVA) using a GLM model. When significant differences were detected with the ANOVA analysis, the differences between the mean values of each sampling time were analysed by Tukey's test. For all the analyses the Statistix version 8.0 for Windows was used (Statistix 8, Copyright@ 1985-2003, Analytical Software, USA) and a $\mathrm{P}<0.05$ was considered statistically significant.

\section{RESULTS AND DISCUSSION}

\section{BLOOD CONSTITUENTS}

The mean concentrations obtained for each blood variable in the different sampling times are shown in table 1 . Sampling time $(\mathrm{P}<0.01)$ significantly affected cortisol concentration and activity of creatine kinase $(\mathrm{CK}$, table 1$)$. The cortisol showed a significant rise $(\mathrm{P}<0.05)$ in its concentration immediately after transport (16.9 ng/ $\mathrm{mL})$. In agreement with the current result, Anderson et al (1999) and Zapata et al (2004) also reported a significant increase in plasma cortisol concentration due to transportation stress in guanacos $\left(37.3 \mathrm{nmol} \mathrm{L}{ }^{-1}\right)$, finding that values returned to baseline $2 \mathrm{~h}$ post-transport $(25.4 \mathrm{nmol}$ $\left.\mathrm{L}^{-1}\right)$. Kannan et al (2000) found that cortisol values in goats decreased to the baseline level at $1 \mathrm{~h}$ after transportation, remained at that level during $18 \mathrm{~h}$ and increased again at $18 \mathrm{~h}$ probably due to feed deprivation stress. According to Tadich et al (2009) the increased cortisol concentration in lambs after transport is likely to be due to the stress of unloading, handling and bleeding procedure, more than to transport itself, especially considering that from the start of the unloading to the time of bleeding there was a 30 minute interval, as in this case also.

Plasma cortisol level is a reliable indicator of stress experienced by an animal (Gregory 1998). Broom et al (1996), who investigated the physiological effects of road transport on sheep, found that loading, penning and start of transport caused an increase in plasma cortisol concentration. They also observed a greater plasma cortisol level during the first 180 min of journey in transported sheep than that of non-transported counterparts. Hall et al (1998) observed the main increase in plasma cortisol level during the first 90 min of journey in sheep. Similarly Kannan et al (2003) found that the cortisol concentrations increased markedly within 1-h after the beginning of transportation in goats.

Loading and unloading are usually the most stressful stages of animal transport (Hall and Bradshaw 1998). The presence of well-designed loading and unloading ramps is critical for minimising stress and improving animal welfare (Grandin 2010). Therefore, methods of loading and unloading might be one of the reasons of high cortisol levels determined in the current study. In Bolivia, the lack of loading ramps on farms and llama slaughterhouses increases animal-handler interactions which could also lead to bruising.

$\mathrm{CK}$ is released into the blood in response to muscle damage, or when there is a vigorous exercise and has been used as indicator of trauma, high levels of physical

Table 1. Means and standard deviation (SD) of the blood concentrations of cortisol, $\beta$-hydroxybutyrate ( $\beta$-OHB) and activity of creatine kinase (CK), at different sampling times during preslaughter handling of llamas.

Promedios y desviaciones estándar (SD) de las concentraciones sanguíneas de cortisol, $\beta$-hidroxibutirato ( $\beta$-OHB) y actividad de creatin quinasa $(\mathrm{CK})$ en las diferentes etapas de muestreo durante el manejo antemortem de las llamas.

\begin{tabular}{lccccc}
\hline \multicolumn{1}{c}{ Response variable } & Before Transport & After Transport & Lairage & At Slaughter & $P$-value \\
\hline Cortisol $(\mathrm{ng} / \mathrm{ml})$ & $2.93 \pm 1.36^{\mathrm{c}}$ & $16.95 \pm 6.37^{\mathrm{a}}$ & $8.58 \pm 4.04^{\mathrm{b}}$ & $10.34 \pm 5.90^{\mathrm{b}}$ & 0.000 \\
$\beta$-OHBA $(\mathrm{mmol} / \mathrm{L})$ & $0.08 \pm 0.06$ & $0.17 \pm 0.11$ & $0.18 \pm 0.10$ & $0.19 \pm 0.13$ & 0.161 \\
$\mathrm{CK}(\mathrm{UI} / \mathrm{l})$ & $135.79 \pm 98.31^{\mathrm{b}}$ & $277.58 \pm 249.85^{\mathrm{ab}}$ & $528.44 \pm 629.98^{\mathrm{a}}$ & $178.27 \pm 73.58^{\mathrm{b}}$ & 0.013 \\
\hline
\end{tabular}

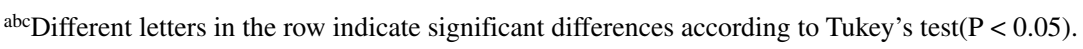


activity or other damages during handling and transport in farm animals (Knowles and Warriss 2007). In the current study, there was a significant increase in CK levels after transport and even higher levels after lairage (table 1). This result could indicate the possible trauma during loading, journey, unloading or injury due to behavioural interaction between animals during the journey. According to Romero et al (2013) truck load density, stops during transport of cattle and lairage time at the plant increased the risk of bruises appearing on carcasses. Other authors have also observed an increase in CK level due to transportation in veal (Grigor et al 2004) and lambs (Tadich et al 2009). As previously demonstrated in sheep, the cortisol concentration tends to increase rapidly (reaction mediated by activity hormones), whereas CK concentrations increase at a slower rate during the pre-slaughter management (reaction mediated by activity enzymes) which is consistent with the findings of the present study.

Mean $\beta$-hydroxybutyrate concentration obtained in the present study, did not change significantly due to the $3 \mathrm{~h}$ transportation stress. However according to results of Saeb et al (2010) and our results, $\beta$-hydroxybutyrate concentration in camels is lower than reference ranges recorded for other ruminants (Ramin et al 2005). According to Chandrasena et al (1979), in dromedary camel the activity of the enzyme $\beta$-hydroxybutyrate dehydrogenase in both the rumen epithelium and the liver is low, and the rumen epithelium is devoid of papillae which would greatly reduce the surface area available for metabolic functions.

The high concentrations of blood variables during exsanguination may be related to the fact that animals were slaughtered by puntilla. Although this method is still accepted for llama slaughter in Bolivia, as observed by Limon et al (2009), most animals showed rhythmic breathing movements at the flank following puntilla stabbing at the atlanto-occipital space, and also had a positive palpebral reflex. The use of the puntilla is not accepted by OIE (2012) animal welfare standards and it is recommended that it should be banned, as it does not properly stun animals.

\section{CARCASS INDICATORS}

Live weight at slaughter was $54.2 \pm 6.4 \mathrm{~kg}$, which is lower than the $63.18 \mathrm{~kg}$ found by Cristofanelli et al (2004, 2005 ) for carcasses of 25 -month old males, and probably reflects the younger age of our llamas (18 to 24 months). Carcasses weighed $26.1 \pm 4 \mathrm{~kg}$ and presented a light and scarce fat coverage $(1.33 \pm 0.46$ in a 1 to 5 point scale). The mean $\mathrm{pH}$ values found for llama meat were $6.84 \pm 0.16$ at $1 \mathrm{~h}$ and $5.42 \pm 0.11$ at $24 \mathrm{~h}$ postmortem, with no final $\mathrm{pH}$ values $>5.8$, which could be considered normal (Cristofanelli et al 2004). Greater initial muscle glycogen content confers an increased capacity for postmortem glycolysis, or high "glycolytic potential," that in turn, extends $\mathrm{pH}$ decline. According to Van Saun (2006) and Cebra et al (2001),
Table 2. Characteristics of bruises found in the carcasses of the llamas. de las llamas.

Características de los hematomas encontrados en las canales

\begin{tabular}{lcr}
\hline $\begin{array}{c}\text { Characteristics } \\
\text { of bruises }\end{array}$ & Class & $\%$ \\
\hline Depth grades & 0 & 69.35 \\
& 1 & 29.03 \\
Patterns & 2 & 1.61 \\
& Circular & 18.75 \\
Color & Irregular & 81.25 \\
& Carcasses without bruising & 69.35 \\
& Bright Red & 29.03 \\
Size & Dark red & 1.61 \\
& Small & 94.74 \\
& Medium & 5.26 \\
\hline
\end{tabular}

llamas and alpacas maintain higher blood glucose concentrations (mean: $7.0 \mathrm{mmol} / \mathrm{l}$, range: $4.6-8.9 \mathrm{mmol} / \mathrm{L}$ ) more similar to that of non-ruminants animals and also display an extreme hyperglycemic response (blood glucose concentrations $>11.1-16.6 \mathrm{mmol} / \mathrm{L}$ ) to even minimal stress situations, a feature which could favor a decrease in $\mathrm{pH}$ in muscle of llamas.

Nine $(30.0 \%)$ of the carcasses were bruised and 21 carcasses $(70.0 \%)$ were recorded as non-bruised. A total of 19 bruises were found on 9 of the carcasses. Table 2 shows that superficial bruises affecting only subcutaneous tissues (grade 1) were the most frequently observed; bruises were mainly classified as small $1(<5 \mathrm{~cm}$ of diameter) and irregularly shaped. These results are similar to those of lamb carcasses as registered by Tarumán and Gallo (2008). According to Carter and Gallo (2008) in lambs transported for up to $12 \mathrm{~h}$, there were only small bruises present in the carcasses, no greater than $5 \mathrm{~cm}$ in diameter. The lesions of small size could be attributed not only to transport, but also loading and unloading, as it was observed that llama were frequently pulled by the fleece or body parts when they refused to move, or to upload and download them manually from the truck. These human-animal interactions have also been observed in sheep (Tarumán and Gallo 2008) and can lead to bruising. During transport, many llamas were seen to lay down and others can trample on them, which can also lead to bruising. Although the handling of the llamas during blood sampling may also have led to some bruising (figure 1e), as they are immobilised by hand only, it was noted that none of them were aggressive during sampling; on the contrary they were very tame. However, most of them vocalised and refused to move at some stage during transfer from the lairage pen to the slaughter area. So, in many opportunities the handlers picked them up from the fleece or other body parts (tail, neck) in order to move them. 
Fresh, bright red-coloured bruises were found more frequently on all the animals $(29.3 \%)$ compared with dark red $(1.6 \%)$. As a bright red colour is characteristic of fresh bruises (Grandin 2000), the observation of bruises of this colour mainly, confirms that lesions were recent (less than 24 hours) and were most likely produced during the immediate pre-slaughter period, probably during transit, at unloading, during lairage or during handling at the slaughterhouse. This has been also found in cattle (Strappini et al 2012) and lambs (Tarumán and Gallo 2008).

It can be concluded that pre-slaughter operations of llamas under the commercial conditions of this study produced physiological changes similar to those associated with a mild and transient stress response as in other species and which, we judge, fall within acceptable limits for their welfare. Considering that llamas are in general tame and have close contact with people, transport stress could be reduced by designing proper loading, unloading facilities and by adequate handling. Although bruises registered were small and superficial, they affected the most valuable cuts. It is highly recommended that OIE standards for the welfare of animals during stunning should be followed and that puntilla use in llamas should be banned. Training of personnel handling llamas at the slaughterhouses in Bolivia would help in improving welfare as well as minimising adverse effects on carcass quality.

\section{ACKNOWLEDGEMENTS}

The authors would like to thank the Government Project MECESUP2 AUS 0601, and the School of Graduates of the Faculty of Veterinary Science, Universidad Austral de Chile for funding this study.

\section{REFERENCES}

Anderson DE, T Grubb, F Silveira. 1999. The effect of short duration transportation on serum cortisol response in alpacas (Lama pacos). Vet J 157, 189-191.

Broom DM, JA Goode, SJL Hall, DM Lloyd, RF Parrott. 1996. Hormonal and physiological effects of a 15-hour road journey in sheep: Comparison with the responses of loading, handling and penning in the absence of transport. BrVet J 152, 593-604.

Carter LM, CB Gallo. 2008. Efectos del transporte prolongado por vía terrestre y cruce marítimo en transbordador sobre pérdidas de peso vivo y características de la canal en corderos. Arch Med Vet 40, 259-266.

Cebra CK, SJ Tornquist, RJ Van Saun, BB Smith. 2001. Glucose tolerance testing in llamas and alpacas. Am J Vet Res 62, 682-686.

Chandrasena LG, B Emmanuel, DW Hamar, BR Howard. 1979. A comparative study of ketone body metabolism between the camel (Camelus dromedarius) and the sheep (Ovis aries). Comp Biochem Physiol 64, 109-112.

Cristofanelli S, M Antonini, D Torres, P Polidori, C Renieri. 2004. Meat and carcass quality from Peruvian llama (Lama glama) and alpaca (Lama pacos). Meat Sci 66, 589-593.

Cristofanelli S, M Antonini, D Torres, P Polidori, C Renieri. 2005. Carcass characteristics of Peruvian llama (Lama glama) and alpaca (Lama pacos) reared in the Andean highlands. Small Rum Res 58, 219-222.
Gallo C, S Pérez, C Sanhueza, J Gasic. 2000. Efectos del tiempo de transporte de novillos previo al faenamiento sobre el comportamiento, pérdidas de peso y algunas características de la canal. Arch Med Vet 32, 157-170.

Gallo C, G Lizondo, T Knowles. 2003. The effects of journey and lairage time on steers transported to slaughter in Chile. Vet Rec 152, 361-364.

Grandin T. 1997. Assessment of stress during handling and transport. J Animal Sci 75, 249-257.

Grandin T. 2000. Livestock handling and transport. $2^{\text {nd }}$ ed. CAB International, Wallingford, Oxon, UK.

Grandin T. 2010. Auditing animal welfare at slaughter plants. Meat Sci 86, 56-65.

Gregory NG. 1998. Animal Welfare and Meat Science. CABI Publishing, New York, USA.

Grigor PN, MS Cockram, WB Steele, J McIntyre, CL Williams, IE Leushuis. 2004. A comparison of the welfare and meat quality of veal calves slaughtered on the farm with those subjected to transportation and lairage. Livest Prod Sci 91, 219-228.

Hall SJG, RH Bradshaw. 1998. Welfare aspects of the transport by road of sheep and pigs. J Applied Animal Welfare Sci 3, 235-254.

Hall SJG, DM Broom, GNS Kiddy. 1998. Effect of transportation on plasma cortisol and packed cell volume in different genotypes of sheep. Small Rum Res 29, 233-237.

Hartung J. 2003. Effects of transport on health of farm animals. Vet Res Comm 27, 525-527.

INE, Instituto Nacional de Estadística, Bolivia. 2008. Encuesta Nacional Agropecuaria. MDRyT, Bolivia, Pp 265-380.

INN, Instituto Nacional de Normalización, Chile. 2002. Norma Chilena de Tipificación de Canales Bovinas. NCH.1306.Of. 2002.

Kannan G, TH Terrill, B Kouakou, OS Gazal, S Gelale, EA Amoah, S Samake. 2000. Transportation of goats: effects on physiological stress response and live weight loss. J Animal Sci 78, 1450-1457.

Kannan G, Kouakou B, Terrill TH, S Gelaye. 2003. Endocrine, blood metabolite, and meat quality changes in goats as influenced by short-term, preslaughter stress. J Anim Sci 81, 1499-1507.

Knowles TG, PD Warriss. 2007. Stress physiology of animals during transport. In: Grandin T (ed). Livestock handling and transport. $3^{\text {rd }}$ ed. CABI Publishing, Oxon, UK, Pp 312-328.

Limon G, J Guitian, NG Gregory. 2009. A note on the slaughter of llamas in Bolivia by the puntilla method. Meat Sci 82, 405-406.

Mamani-Linares LW, C Gallo. 2013 . Effects of a feed supplementation given during the dry season on performance and carcass traits of grazing llama (Lama glama). Small Rum Res 114, 233-239.

Mamani LW, C Gallo. 2013 ${ }^{\mathrm{b}}$. Meat quality attributes of the Longissimus lumborum muscle of the Kh`ara genotype of llama (Lama glama) reared extensively in northern Chile. Meat Sci 94, 89-94.

Miranda-de la Lama GC, M Villarroel, MM Campo, JL Olleta, C Sañudo, GA María. 2012. Effects of double transport and season on sensorial aspects of lamb's meat quality in dry climates. Trop Anim Health Prod 44, 21-27.

OIE, World Organisation for Animal Health. 2012. Terrestrial Animal Health Code. Chapter 7. Animal Welfare. World Organization for Animal Health, Paris, France.

Ramin AG, S Asri, R Majdani. 2005. Correlations among serum glucose, beta-hydroxybutyrate and urea concentrations in non-pregnant ewes. Small Rum Res 57, 265-269.

Romero MH, LF Uribe-Velásquez, JA Sánchez, GC Miranda-de la Lama. 2013. Risk factors influencing bruising and high muscle $\mathrm{pH}$ in Colombian cattle carcasses due to transport and pre-slaughter operations. Meat Sci 95, 256-263.

Saeb M, H Baghshani, S Nazifi, S Saeb. 2010. Physiological response of dromedary camels to road transportation in relation to circulating levels of cortisol, thyroid hormones and some serum biochemical parameters. Trop Anim Health Prod 42, 55-63. 
Statistix 8, Copyright ${ }^{\oplus} 1985-2003$. Statistix version 8.0 for Windows, Analytical Software, USA

Strappini AC, JHM Metz, CB Gallo, B Kemp. 2009. Origin and assessment of bruises at slaughter. Animal 3, 728-736.

Strappini AC. 2010. Problemas y errores más comunes encontrados en Chile durante el manejo del ganado. En: Mota-Rojas D, GuerreroLegarreta I, Trujillo-Ortega ME (eds). Bienestar animal y calidad de la carne. Editorial B.M., México DF, México, Pp 157-169.

Strappini AC, K Frankena, JHM Metz, C Gallo, B Kemp. 2012. Characteristics of bruises in carcasses of cows sourced from farms or from livestock markets. Animal 6, 502-509.
Tadich N, C Gallo, ML Brito, DM Broom. 2009. Effects of weaning and $48 \mathrm{~h}$ transport by road and ferry on some blood indicators of welfare in lambs. Livest Sci 121, 132-136.

Tarumán JA, CB Gallo. 2008. Contusiones en canales ovinas y su relación con el transporte. Arch Med Vet 40, 275-279.

Van Saun R. 2006. Nutrient requirements of South American camelids: A factorial approach. Small Ruminant Res 61, 165-186.

Zapata B, J Gimpel, C Bonacic, BA González, JL Riveros, AM Ramírez, F Bas, DW MacDonald. 2004. The effect of transport on cortisol, glucose heart rate, leukocytes and body weight in captive-reared guanacos (Lama guanicoe). Animal Welfare 13, 439-444. 